\title{
REFLEXÕES DE PROFESSORAS DE EDUCAÇÃO INFANTIL SOBRE A CONDIÇÃO FEMININA NA DOCÊNCIA
}

\author{
Kelly Jessie Queiroz Penafiel ${ }^{*}$ \\ Claudiane Alencar da Silva** \\ Marli Lúcia Tonatto Zibetti***
}

\begin{abstract}
Resumo: Este artigo teve como objetivo investigar como as professoras que atuam na Educação Infantil em escolas municipais de Vilhena, Rondônia, compreendem o seu próprio trabalho e as questões de gênero no âmbito da docência. A pesquisa seguiu a abordagem qualitativa e utilizou como instrumento de coleta de dados a entrevista. Participaram do estudo quatro professoras. Os resultados demonstram concepções reducionistas sobre o protagonismo feminino na docência e uma associação da figura materna, carinhosa e abnegada, ao ideal de professora. As constatações se sustentam na concepção da "inclinação natural" da mulher para o cuidado. É notório que a questão de gênero precisa ser explorada nos currículos dos cursos de formação inicial, aprofundando as discussões sobre o tema, com o objetivo de abandonar discursos e práticas que fomentam a desigualdade de gênero.
\end{abstract}

Palavras-chave: Mulheres. Professoras. Educação Infantil.

\section{REFLECTIONS OF FEMALE TEACHERS IN CHILDHOOD EDUCATION ABOUT THE FEMALE CONDITION IN TEACHING}

\begin{abstract}
This article had as its objective to investigate how the teachers who work in Early Childhood Education in municipal schools in Vilhena, state of Rondônia, understand their own work and the gender issues related to teaching. The research adopted a qualitative approach and used as the instrument of data collection the interview. Four teachers participated in the study. The results of the research demonstrate reductionist conceptions about female protagonism in teaching and an association of the maternal figure, affectionate and selfless, to the ideal teacher. The findings are based on the concept of the women's "natural tendency" for care. It is notorious that the gender issue needs to be explored in the curricula of the initial training courses, deepening the discussions on the subject, with the aim of abandoning discourses and practices that foment gender inequality.
\end{abstract}

Keywords: Women. Female teachers. Children's education.

Submissão 25-10-19 Aceite 25-10-19

\section{INTRODUÇÃO}

Esta pesquisa teve como objetivo investigar como as mulheres-professoras que atuam na Educação Infantil em uma escola da rede municipal de ensino em Vilhena, Rondônia, compreendem seu trabalho, o que pensam sobre a forte presença feminina no magistério e como veem as questões de gênero no âmbito escolar. Portanto, do ponto de vista teórico, dedicamo-nos a estudar as mudanças históricas da condição feminina ao longo dos tempos, as conquistas em relação aos direitos de educação e cidadania por parte das mulheres e também o ingresso do público feminino no magistério. Destinamos atenção especial aos textos que apontam as transformações ocorridas no magistério

\footnotetext{
* Doutoranda em Educação (UFMG). Mestre em Psicologia e graduada em Pedagogia pela Universidade Federal de Rondônia (UNIR). Professora na Universidade Federal de Rondônia (UNIR).

** Graduada em Pedagogia pela Universidade Federal de Rondônia (UNIR).

*** Doutora e Mestre em Psicologia Escolar e do Desenvolvimento Humano pela Universidade de São Paulo (USP). Professora da Universidade Federal de Rondônia (UNIR).
} 
a partir da predominância das mulheres nessa profissão. Adotamos como fundamentação teórica autoras e autores como Louro (1997, 2006; 2011), Lopes e Galvão (2001) e Bourdieu (2002; 2007), entre outras/os.

Os dados empíricos foram obtidos por meio de entrevistas individuais semiestruturadas, conforme explicitaremos na seção relativa aos percursos metodológicos. Tendo por base essas entrevistas, nossa análise voltou-se para as razões que levaram as professoras a ingressar na profissão, as explicações que dão para a feminização do magistério e quais os aspectos do trabalho docente que consideram mais prazerosos. Com este trabalho, pretendemos esclarecer como as relações de gênero interferem em nossas escolhas profissionais e em ações durante a atuação docente. Lembramos que quaisquer análises são sempre inacabadas e marcadas por uma incompletude do dizer.

Este artigo está organizado em cinco seções, para além desta introdução. Na segunda seção, abordaremos a trajetória histórica da educação feminina. Mostraremos como se deu a inserção das mulheres nas escolas e, posteriormente, nas faculdades, e como se chegou a uma feminização do magistério. Em seguida, apresentamos a seção que descreve os procedimentos metodológicos da pesquisa. Na seção cinco, trazemos os resultados e as discussões. Por último, na seção seis, apresentamos as considerações finais.

O FEMININO E A EDUCAÇÃO: A feminização do trabalho docente

Até por volta do século XVII, o pensamento predominante sobre a educação feminina era o de que as mulheres deveriam ser mais "educadas" do que "instruídas" ou seja, nessa época, o conceito de educação estava atrelado à formação moral (LOURO, 2006). Defendia-se que as mulheres não precisavam de instrução formal, mas de bons princípios morais, já que destino delas seria o casamento e as tarefas de dona de casa, mãe e educadora dos filhos.

Louro (2006) afirma que, quando as meninas tiveram acesso à escola no Brasil, as aulas eram ministradas em turmas separadas por sexo. Sendo assim, quem lecionava para as meninas era uma mulher, e disso resultaram as primeiras vagas exclusivamente femininas no magistério. No entanto, essa educação se resumia à continuação do que as alunas aprendiam em casa: cuidar do lar e ser uma esposa abnegada e uma mãe zelosa. $\mathrm{Na}$ sociedade patriarcal, ler e escrever foram consideradas atividades perigosas para a alma e o caráter "frágil” das mulheres (LOURO, 2006). 
A vinda da família real para o Brasil em 1808 começou lentamente a modificar o conceito de ensino ofertado às mulheres. Após a Proclamação da Independência, em 1822, foram criados os ensinos primário e secundário. Contudo, o ensino secundário ainda não era aconselhável para o público feminino, pois era considerado de caráter masculino (LOPES; GALVÃO, 2001).

$\mathrm{O}$ ingresso das mulheres no mercado de trabalho e as conquistas femininas no âmbito legal foram fruto de lutas que contribuíram para que novos espaços fossem ocupados. Um desses espaços foi o escolar. As mulheres passaram, então, a assumir a hegemonia na carreira do magistério. Carvalho (1999) afirma que a discussão em torno da feminização do magistério é, sem dúvida, bastante complexa e existem diferentes olhares para essa realidade. A entrada das mulheres nessa carreira não ocorreu por concessão masculina, mas representou o fruto de lutas para conquistar espaço social e profissional.

Não se pode ignorar que o pensamento patriarcal valorizava a mulher apenas como mãe e esposa, o que a tornava a principal responsável pela primeira educação dos filhos, base da família e da pátria. Essa concepção teve influência na maciça feminização do magistério. Louro (2006) relembra que argumentos religiosos e higienistas procuram responsabilizar a mulher pela manutenção da família saudável. Segundo a autora, esses argumentos foram somados aos novos conhecimentos científicos da Psicologia do final do século XIX, que enfatizavam a privacidade familiar e o amor materno como indispensáveis ao desenvolvimento de toda criança. Portanto, a ocupação do magistério pelas mulheres se deu também pelo fato da educação da primeira infância ser vista como uma extensão daquela ministrada em casa. Nesse contexto, surge a ideia de que ser professora era "vocação" da mulher, já que esta possuiria paciência e delicadeza, características vistas como naturais ao público feminino e indispensáveis à educação (LOURO, 2006).

Não podemos deixar de mencionar a dupla jornada de trabalho a que as mulheres trabalhadoras tiveram que se submeter. Trabalhar fora do lar não as dispensava dos trabalhos domésticos; pelo contrário, o trabalho remunerado não devia e nem podia atrapalhá-las em suas obrigações de donas de casa, esposas dedicadas e mães zelosas. Assim, o magistério, para muitas, tornou-se uma "cópia" do trabalho doméstico. Para Louro (2006), a formação das professoras, a partir da influência das teorias psicológicas, enfatizou a relação entre docência, cuidado e afeto. Ainda segundo a autora, as escolas de formação de professoras assumiam uma postura ambígua 
e contraditória, uma vez que, ao mesmo tempo em que preparavam as professoras para romper com o ensino desenvolvido nos lares, defendendo a maior capacidade da escola no trabalho de ministrar os conhecimentos exigidos pela sociedade, enfatizavam, por outros meios, a ligação entre a docência e o ambiente familiar quando baseavam a formação nas referências à maternidade e ao afeto.

É consenso que a educação é indispensável para o desenvolvimento de uma nação. Nesse contexto, a educação feminina e o papel da mulher na sociedade nos moldes descritos anteriormente caracterizam uma abordagem marcada por desigualdades entre os gêneros, especialmente em relação às questões sociais e culturais. As mulheres professoras ocupam a maioria dos cargos no campo da educação, principalmente nas primeiras etapas do Ensino Fundamental. O que isso representa? O que elas pensam sobre a sua profissão?

Para responder a essas questões, é preciso um olhar mais atento para a formação de professoras e o grande contingente de mulheres envolvidas na profissão de educar. Conforme nos lembra Louro (2006), as mulheres brasileiras, tanto em sala de aula como em outros espaços sociais, viveram diferentes situações nas quais exerceram e sofreram relações de poder. Portanto, compreender essa trajetória como marcada somente pela submissão é empobrecer "demasiadamente sua história, uma vez que, mesmo nos momentos e nas situações em que mais se pretendeu silenciá-las e submetê-las, elas também foram capazes de engendrar discursos discordantes, construir resistências, subverter comportamentos" (LOURO, 2006, p. 479).

Como podemos observar, não foi uma mera coincidência que fez com o quadro docente dos anos iniciais da Educação Básica fosse majoritariamente composto por mulheres. Essa realidade mostra como nossa cultura e a atribuição de papéis sociais é atravessada por questões de gênero. Sobre essa perspectiva, Pereira e Favaro (2016, p. 5) afirmam que "no âmbito desse aparato ideológico e cultural, a mulher era considerada como o 'sexo frágil' e foi designada para o mundo privado, ou seja, dedicada aos cuidados domésticos e maternais".

Antes da Revolução Industrial, a docência era majoritariamente exercida por homens, pois apenas eles tinham o direito de estudar e, consequentemente, de se tornar professores. Hahner (2011, p. 467) afirma que "no Brasil, como em muitos outros países do mundo ocidental, o magistério primário passou de ocupação majoritariamente masculina, em meados do século XIX, para a ocupação feminina, no século XX [...]”. Entretanto, devemos lembrar que essa mudança não aconteceu da noite para o dia. 
Pereira e Favaro (2016, p. 5) argumentam que, devido à forte influência religiosa na família brasileira, durante muito tempo, por meio de uma imposição cultural, a mulher acreditou "que seu papel na sociedade era apenas a reprodução biológica, o cuidado com o lar e o marido. Havia um evidente receio quanto à liberação da educação feminina e quanto ao seu ingresso no mercado de trabalho". As primeiras escolas que aceitavam meninas não ensinavam às alunas línguas, aritmética e ciências; os ensinamentos eram voltados para as tarefas domésticas. Os mesmos autores acrescentam que "esse cenário, entretanto, não foi exclusividade da história brasileira. Também na Europa a mulher ocupava um lugar inferior na hierarquia social, estando suas funções moralmente associadas aos cuidados com o lar, o marido e os filhos" (PEREIRA; FAVARO, 2016, p. 5).

No decorrer do século XIX, o Brasil começa a enriquecer com a exportação do café, o que favorece a emergência de segmentos urbanos. A classe média se fortalece e passa a ter ambições agora no comércio exterior, com a sociedade se modernizando e as pessoas saindo da área rural para morar nas cidades. Com a nova sociedade emergente, era necessário modificar os cidadãos, tornar a nação moderna e civilizada e adaptada às inovações tecnológicas, aos novos costumes e ao progresso. Para que esses projetos fossem alcançados, era necessário "remover elementos arcaicos enraizados na sociedade e remanescentes da vida colonial, sendo um deles a reclusão da população feminina, outro, seu atraso, em tudo homólogo ao analfabetismo da maior parte da população, crianças e adultos" (LAJOLO; ZILBERMAN, 2007, p. 432). As autoras acrescentam ainda que, nesse clima favorável, a educação das mulheres também levantou a bandeira do ensino obrigatório garantido pelo Estado.

Lajolo e Zilberman (2007) enfatizam que a escolarização feminina no Brasil foi permitida com base no pretexto de que elas poderiam ajudar na concretização do plano político pensado para o país; essa educação para todos seria promovida sob a mesma finalidade de uma liberdade para todos. Formar a mulher podia significar capacitar, consequentemente, as professoras para um mercado de trabalho que precisava se expandir. Pereira e Favaro (2016, p. 7) concluem que "com a ampliação cada vez maior das indústrias e o crescente urbanismo, os homens foram em busca de outros empregos, geralmente melhor remunerados, o que possibilitou um maior número de vagas disponíveis no magistério para as mulheres".

Como eram poucas as alternativas de trabalho para as mulheres que tinham certo grau de instrução e status, lecionar passou a ser uma opção viável, embora os salários 
fossem inferiores aos dos homens. Ser professora representou para muitas a possibilidade de alcançarem maior independência econômica (HAHNER, 2011). Segundo Lajolo e Zilverman (2007, p. 432), a "mulher, que em princípio educava os filhos, poderia ser também a mestra de todos, estendendo para fora de casa a tarefa para a qual fora talhada". Conforme já adiantamos, culturalmente, a figura da mulher está ligada à responsabilidade da formação do homem, sendo aquela que educa as crianças.

Ao possibilitar às mulheres a prática do estudo, o Estado resolveu o problema da falta de mão de obra para o magistério, que era uma profissão pouco procurada e remunerada. Com o ingresso desse público na profissão docente, os governos não se viam mais obrigados a oferecer melhores condições salariais, já que o salário da mulher não precisava e nem poderia ser maior que do homem - era necessário apenas complementar o do patriarca (LAJOLO; ZILBERMAN, 2007). Pereira e Favaro (2016) acrescentam que o crescimento de mulheres alfabetizadas nos grandes centros contribuiu para o ingresso da mulher na docência, mas acabou gerando as condições materiais para que muitas professoras fossem contratadas por salários inferiores.

A entrada do público feminino em sala de aula evidenciou a " [...] noção de que a sociedade carecia de mulheres instruídas, educadas, porém, para as necessidades do grupo social, e não da própria mulher" (LAJOLO; ZILBERMAN, 2007, p. 439). Hahner (2011, p. 469) complementa esse raciocínio ao comentar que, ao educar mulheres e, consequentemente, torná-las professoras, seriam reduzidos certos gastos do Estado: “como em outros países católicos, ela [a mulher] era aceita apenas por uma questão econômica, particularmente em cidades onde o ensino separado entre os sexos demonstrava que os custos eram muito elevados".

Pereira e Favaro (2016) ressaltam que, durante muito tempo, predominou o discurso de que a docência exercida pelas mulheres deveria ser compreendida como uma atividade de amor, de entrega e de doação. Isso acabou por contribuir para uma má remuneração do trabalho feminino e fomentou a terrível concepção de que as professoras devem trabalhar por "vocação" e "amor". Hahner (2011, p. 467) acrescenta que "sem negar a grande importância de fatores econômicos e do discurso do ensino como uma extensão da função maternal [...], a maternidade espiritual serviu como uma justificativa para empregar mais, e mais barato, professoras".

Portanto, pode-se afirmar que, mesmo com a possibilidade de saírem de casa para trabalhar, as mulheres não se libertaram das amarras machistas da sociedade. Elas continuaram exercendo o papel da dona de casa, a que lava, passa, faz comida 
para o marido e cuida dos filhos, assim como foram ensinadas pelas avós, mães, tias (ZIBETTI; PEREIRA, 2010). Apesar disso, como acontece com todo fenômeno de opressão, a manutenção desse sistema patriarcal "também está relacionada com a internalização de valores e práticas dominantes por parte dos/as oprimidos/as" (ZIBETTI; PEREIRA, 2010, p. 263).

De fato, as mulheres têm consciência de sua condição, e muitas, mesmo criticando a exploração vivida no mundo doméstico, partilham e repetem opiniões e comportamentos hegemônicos, deixando sempre recair sobre elas os afazeres domésticos. Ainda nessa trilha de pensamento, Bourdieu (2002, p. 156) acrescenta que "o sistema de oposições fundamentais conservou-se, transformando-se, através das mudanças que foram determinadas pela revolução industrial e que afetaram as mulheres de maneira diferente segundo sua posição na divisão do trabalho".

No que diz respeito à docência feminina na Educação Infantil, Venturini e Thomasi (2013, p. 6) comentam a importância de se pensar em "[...] políticas públicas brasileiras para a Educação Infantil e a formulação de políticas públicas visando à superação da questão do sexismo na educação e das desigualdades de gênero, contemplando as mais variadas formas de construção da feminilidade e da masculinidade". Muitas coisas foram conquistadas pelas mulheres por meio de movimentos sociais e de constante militância. Hoje elas são maioria nas salas de aula e podem fomentar a discussão sobre a desigualdade de gênero, ou fazer a diferença na descaracterização dos estereótipos de gênero nas relações infantis.

\section{A PESQUISA}

Esta pesquisa procurou investigar a maneira como as mulheres-professoras que atuam na Educação Infantil em escolas da rede municipal de ensino em Vilhena, Rondônia, compreendem as questões de gênero no âmbito do magistério. Para atendermos ao objetivo proposto, a abordagem escolhida procurou priorizar a fala das envolvidas, criando espaços de discussão no quais elas fossem estimuladas a contar as razões de suas escolhas, as oportunidades e as possibilidades que garantiram seu ingresso na profissão, bem como as explicações que têm para a feminização da docência. Para isso, optamos pela técnica de entrevistas individuais com roteiro semiestruturado. 


\section{PARTICIPANTES DO ESTUDO}

Participaram da pesquisa quatro professoras da Educação Infantil de duas escolas da rede municipal de ensino de Vilhena. Os convites para a participação no estudo foram feitos diretamente às professoras. Procurando garantir o anonimato das informantes, utilizamos aqui apenas as iniciais "K", "M", "P" e "W" como forma de as identificar. No quadro 1, apresentamos os dados dessas participantes.

QUADRO 1 - Perfil das participantes do estudo

\begin{tabular}{|c|c|c|c|c|c|c|}
\hline \multirow[b]{2}{*}{ Professora } & \multirow[b]{2}{*}{ Idade } & \multirow[b]{2}{*}{ Formação } & \multicolumn{2}{|c|}{ Atuação profisssional } & \multirow[b]{2}{*}{$\begin{array}{l}\text { Estado } \\
\text { civil }\end{array}$} & \multirow[b]{2}{*}{ Filhos } \\
\hline & & & $\begin{array}{c}\text { Como } \\
\text { docente }\end{array}$ & $\begin{array}{c}\text { Tempo de } \\
\text { docência } \\
\text { na } \\
\text { Educação } \\
\text { Infantil }\end{array}$ & & \\
\hline K & 43 & $\begin{array}{l}\text { Graduação em Letras } \\
\text { com Pós-Graduação } \\
\text { em Psicopedagogia }\end{array}$ & 17 anos & 5 anos & Solteira & $\begin{array}{l}\text { Sem } \\
\text { filhos }\end{array}$ \\
\hline M & 43 & $\begin{array}{l}\text { Graduação em } \\
\text { Pedagogia }\end{array}$ & 7 anos & $\begin{array}{l}4 \text { anos } \\
\text { e meio }\end{array}$ & Casada & 1 filho \\
\hline $\mathrm{P}$ & 37 & $\begin{array}{c}\text { Graduação em } \\
\text { Pedagogia com } \\
\text { Pós-Graduação em } \\
\text { Gestão, Orientação } \\
\text { e Psicopedagogia }\end{array}$ & 17 anos & 10 anos & Solteira & $\begin{array}{l}\text { Sem } \\
\text { filhos }\end{array}$ \\
\hline W & 51 & $\begin{array}{l}\text { Graduação em } \\
\text { Pedagogia }\end{array}$ & 15 anos & 2 anos & Casada & 3 filhos \\
\hline
\end{tabular}

FONTE: Entrevistas (2018).

As participantes têm idade entre 37 e 51 anos. Quanto à formação acadêmica, três são licenciadas em Pedagogia e uma é formada em Letras. Além da formação inicial, as professoras K e P possuem Pós-graduação Lato Sensu em Psicopedagogia e Gestão e Orientação. O tempo de atuação profissional na docência varia entre sete e 17 anos. Especificamente na Educação Infantil, as entrevistadas apresentam tempo de experiência que vai de dois a dez anos. Vale destacar que a jornada de trabalho docente das entrevistadas é de 40 horas semanais, com exceção da professora M, que cumpre uma carga horária de 30 horas. Quanto ao estado civil, as professoras $\mathrm{M} \mathrm{e} \mathrm{W}$ são casadas. O número de filhos varia entre um e três.

Consideramos esses dados relevantes para a pesquisa, uma vez que o estado civil e o número de filhos são determinantes para o enfrentamento de dupla jornada 
de trabalho por parte das entrevistadas. Apesar da conquista de direitos igualitários em várias áreas, os serviços domésticos ainda são destinados em primeiro lugar à mulher. Mesmo que ela tenha uma ocupação formal fora de casa da mesma forma que o homem, ainda assim é responsável pelas lides domésticas e pela educação das crianças. Conforme afirmam Zibetti e Pereira (2010, p. 263), "ainda há uma enorme distância entre a igualdade defendida pelas mulheres e também pela sociedade e as práticas sociais em curso nos ambientes domésticos". As autoras (2010, p. 265) alertam que "[...] pouca ênfase tem sido dada à questão da sobrecarga feminina com o trabalho doméstico, acentuada pelas demandas do trabalho docente que, pela falta de tempo destinado a essas tarefas no ambiente escolar, invade a vida privada".

\section{INSTRUMENTOS DE COLETA DE DADOS}

Após a assinatura do termo de Consentimento Livre e Esclarecido, as participantes foram entrevistadas individualmente. $\mathrm{O}$ roteiro de entrevista contou com 14 questões; no entanto, durante as conversas, outras questões foram feitas, o que proporcionou um melhor entendimento das concepções das participantes. Cada entrevista durou em média 40 minutos. Os arquivos em áudio foram transcritos para posterior análise e apagados em seguida. As respostas fornecidas pelas participantes foram analisadas em articulação com o referencial teórico adotado neste estudo.

As respostas possibilitaram a criação dos seguintes eixos temáticos para a análise: motivos que levaram à escolha da profissão docente; satisfação quanto ao trabalho docente; condições de trabalho; horas dispendidas com outras atividades; trabalho profissional e doméstico; consequências da dupla jornada de trabalho; docência e gênero; predominância feminina na educação/predominância feminina na Educação Infantil; educação das meninas na escola; violência de gênero; e, por fim, temática feminina nos cursos de formação inicial.

RESULTADOS E DISCUSSÕES: O que dizem as professoras sobre sua profissão?

A professora que atua na Educação Infantil precisa de uma formação de nível superior. Nesse contexto, exige-se da docente que adote uma concepção de criança 
como sujeito histórico, social e biológico. Além disso, espera-se que essa profissional seja preparada, criativa, dinâmica e atualizada. Observamos que as cobranças sociais que recaem sobre a docente têm acarretado uma sobrecarga de responsabilidades. Esta profissional deve ser polivalente, capaz de dar conta de todas as ações pertinentes ao atendimento das crianças e à articulação dos conteúdos para o desenvolvimento de projetos e, além disso, deve saber identificar as necessidades básicas dessa faixa etária.

De acordo com Carvalho (1999, p. 72), “desde a Segunda Guerra até os dias atuais, a família vem sofrendo grandes transformações com relação às ideias sobre infância, sobre o lugar social destinado às mulheres e às relações entre os sexos, como o testemunham os intensos debates no interior da sociologia da família". Em meio às grandes transformações no âmbito educacional, especificamente no que se refere às crianças de zero a cinco anos, algumas ideias e conceitos sobre a professora da Educação Infantil permanecem inalteradas. Carvalho (1999) destaca ainda que, do ponto de vista histórico e cultural, a mulher sempre foi encarregada de educar e cuidar dos filhos. A construção da imagem social da professora da Educação Infantil está mergulhada nessa concepção assistencialista e vinculada ao estereótipo de "missão feminina". Diante disto, procuramos saber das entrevistadas as razões que as levaram à escolha da docência como profissão, especialmente na Educação Infantil. No quadro seguinte, apresentamos as respostas. Todas as falas das entrevistadas são transcritas neste trabalho exatamente como foram proferidas e, portanto, foram mantidas marcas discursivas próprias da oralidade.

QUADRO 2 - Motivos que levaram à escolha da profissão docente

\begin{tabular}{|c|l|}
\hline \multicolumn{2}{|c|}{ Quais as suas razões para a escolha desta profissão? } \\
\hline & $\begin{array}{l}\text { É porque na época que eu comecei a estudar foram as } \\
\text { condições... A questão da mensalidade do curso, e eu já era } \\
\text { casada. Depois de 15 anos que voltei a estudar, seria mais } \\
\text { por isso, pela facilidade, né? Eu fiz um curso à distância, } \\
\text { não foi todos os dias, era uma vez por semana, e durante o } \\
\text { curso eu fui gostando [...]. Me identifiquei e então fui até } \\
\text { o final. }\end{array}$ \\
\hline Olha, falando bem a verdade, é que aqui não tinha outra \\
opção [...]. Quando eu escolhi Pedagogia, é que eu não tinha \\
outra opção, mas, depois que iniciei, eu me apaixonei pelo \\
curso e acho, assim, que todo mundo deveria fazer \\
Pedagogia. É uma área que você aprende muito sobre a \\
questão da formação humana, não é só da formação da \\
criança, mas o desenvolvimento humano.
\end{tabular}




\begin{tabular}{|l|l|}
\hline Professora $\mathrm{K}$ & Amor ao conhecimento. \\
\hline \multirow{3}{*}{ Professora W } & $\begin{array}{l}\text { Eu fiquei } 20 \text { anos fora de sala de aula. Fiz magistério; como } \\
\text { eu era auxiliar de enfermagem, na época eu ganhei as contas } \\
\text { do Bianco }{ }^{1} \text {. Aquela vez que o governador Bianco deu as } \\
\text { contas, aí surgiu a oportunidade de eu fazer um novo } \\
\text { concurso. Eu peguei os conteúdos de técnico de enfermagem } \\
\text { [e] achei bastante difícil. Achei mais fácil fazer de } \\
\text { professores na área de educação. Aí, assim, eu fiz } \\
{[\text { Pedagogia]. Por esse motivo, eu escolhi fazer Pedagogia. }}\end{array}$ \\
\hline
\end{tabular}

FONTE: Entrevistas (2018).

Pio, França e Domingues (2017) alertam para o fato de que ser professora tornou-se uma profissão provisória, um trabalho não desejado, que se faz na falta de outra opção. Pinto (2010) ressalta que a profissão docente não é uma opção promissora, com condições salariais atraentes para quem a escolhe. $\mathrm{Na}$ fala das entrevistadas, é possível perceber que a escolha profissional aconteceu por acaso para as professoras $\mathrm{M}, \mathrm{P}$ e $\mathrm{W}$, o magistério significou a única opção de prosseguir os estudos.

Destoa dessas falas a da Professora K, mas a sua resposta nos parece um tanto estereotipada. O lugar-comum do "amor pelo conhecimento" parece remeter à ideia de que ser professora da Educação Infantil assume um caráter de sacerdócio. Ao analisarem tal concepção, Zibetti e Pereira (2010) salientam que o trabalho docente passou a ser exercido como "missão feminina" desde o período de consolidação como profissão até os dias atuais, o que se evidencia pela grande maioria de mulheres nessa função.

Essas concepções levam-nos a questionar se, no exercício da docência, as entrevistadas encontram satisfação e realização profissional. Nesse sentido, procuramos saber o que, no trabalho docente, lhes dá prazer. No quadro 3, são apresentadas as respostas a essa questão.

QUADRO 3 - Satisfação no trabalho docente

\section{O que dá mais prazer no trabalho como professora?}

${ }^{1}$ A entrevistada faz referência a José de Abreu Bianco, que governou o estado de Rondônia no período de 1999 a 2002. Bianco demitiu, por meio de decreto, mais de 9 mil servidores públicos estaduais, como forma de adequação da folha de pagamento, tendo como fundamento a Lei Complementar n. ${ }^{\circ}$ 82/1995 (Lei Camata). Na época, foram exonerados servidores celetistas, emergenciais e recém-concursados. 


\begin{tabular}{|c|l|}
\hline \multirow{3}{*}{ Professora P } & $\begin{array}{l}\text { É você ver o seu trabalho sendo reconhecido e ver a criança } \\
\text { aprendendo. Você vê aquilo que está aplicando, ensinando, } \\
\text { sendo desenvolvido nas crianças. Ver aprendendo com } \\
\text { alegria, com prazer. Ver o seu trabalho assim sendo } \\
\text { reconhecido neles mesmo, não é o reconhecimento, assim, } \\
\text { para nós, mas o reconhecimento no aprendizado deles. }\end{array}$ \\
\hline Professora K & $\begin{array}{l}\text { Fomentar o conhecimento e poder contribuir para o } \\
\text { aprendizado dos alunos. }\end{array}$ \\
\hline Professora W & $\begin{array}{l}\text { Olha, eu, como gosto da alfabetização, o que me dá mais } \\
\text { prazer é eu pegar uma criança começando ali quando está na } \\
\text { primeira série ou saindo da primeira, e tem aquela ansiedade } \\
\text { para aprender, né? Eu gosto de buscar, fazer pesquisa... } \\
\text { Eu gosto, eu amo quando a criança começa a desenvolver, ler. } \\
\text { E começa a produzir aqueles textinhos simples. Então, eu } \\
\text { amo ser alfabetizadora. }\end{array}$ \\
\hline
\end{tabular}

FONTE: Entrevistas (2018).

São frequentes as referências ao afeto, ao carinho, ao amor pelas crianças. Ainda está presente a concepção de docência na Educação Infantil como sendo uma continuidade do trabalho materno. Pode-se perceber como essas falas carregam marcas do passado de uma sociedade patriarcal, regida por rigorosos valores classistas e moralistas a respeito do que representa a docência feminina. Sobre esse aspecto, é oportuno citarmos Del Priore (2007, p. 454), que afirma que "[...] ao se feminizarem, algumas ocupações, a enfermagem e o magistério, por exemplo, tomaram emprestado as características femininas do cuidado, sensibilidade, amor, vigilância etc.". A representação da professora que educa seus alunos como uma mãe educa os filhos, com amor, paciência, afetividade e doação, permanece atrelada ao ideal de professora das entrevistadas. Timidamente, as professoras $\mathrm{P}, \mathrm{K}$ e W apontam o reconhecimento da função docente e o sucesso dos alunos como fontes de prazer no exercício da docência, mas não abandonam as referências ao amor.

Com o ingresso das mulheres na profissão docente, nota-se uma crescente desvalorização profissional e salarial. Essa mesma desvalorização levou ao abandono da profissão pelos homens. Durante muito tempo, imperou sem qualquer tensionamento o discurso de que caberia à mulher educar as crianças e que tal atividade "natural" não merecia ser remunerada de forma justa, já que constituía parte da "missão feminina" (LAJOLO; ZILBERMAN, 2007).

Além disso, ainda hoje, a falta de reconhecimento e de condições de trabalho e o baixo salário das professoras fazem com que seja frequente que essas profissionais procurem uma fonte de renda alternativa. Confirmando essa realidade, nossas entrevistadas informaram que, além da docência, exercem ou já exerceram 
outra ocupação remunerada. Isso evidencia que a jornada de trabalho dessas mulheres é muito maior do que se acredita. Muitas delas enfrentam uma dupla e até mesmo tripla jornada laboral. Há também que se considerar que o trabalho das professoras vai além da sala de aula; assim, sobra pouco tempo para elas se dedicarem a atividades pessoais e de lazer. Considerando essa realidade, procuramos interrogar as entrevistadas sobre quanto tempo dispunham para se dedicar a outras atividades que não a da docência ou dos afazeres domésticos. No quadro 4, organizamos as respostas.

QUADRO 4 - Horas gastas com outras atividades

\begin{tabular}{|c|l|}
\hline \multicolumn{2}{|c|}{$\begin{array}{c}\text { Quantas horas por semana gasta com outras atribuições } \\
\text { além do tempo que está na escola? }\end{array}$} \\
\hline Professora M & $\begin{array}{l}\text { Eu trabalho na parte da manhã, das sete às três horas. Aí, eu } \\
\text { tenho o restante da tarde pra eu cuidar da casa. Eu tiro duas } \\
\text { horas por dia pra terminar meu planejamento, porque não dá } \\
\text { para fazer ele todo no meu horário de serviço. }\end{array}$ \\
\hline Professora $\mathrm{P}$ & $\begin{array}{l}\text { Olha, hoje em dia praticamente quase nada, porque tem me } \\
\text { sobrado pouco tempo. }\end{array}$ \\
\hline Professora $\mathrm{K}$ & $\begin{array}{l}\text { Quando não estou trabalhando em sala de aula ou planejando, } \\
\text { uso todas as horas comigo. }\end{array}$ \\
\hline Professora $\mathrm{W}$ & $\begin{array}{l}\text { Eu acredito que a gente que é mulher, né?, nós conseguimos } \\
\text { dividir bem nosso tempo, porque nós temos planejamento. } \\
\text { Aí, conseguimos tal hora para fazer unha, outra hora para ir } \\
\text { à igreja [...]. }\end{array}$ \\
\hline
\end{tabular}

FONTE: Entrevistas (2018).

Quando se pensa no trabalho das professoras, tem-se a ilusão de que essa atividade se reduz àquela realizada no espaço escolar. Contudo, sabemos que as reais condições de trabalho não levam em conta as horas dedicadas a fazer pesquisas, planejar aulas, produzir jogos e atender às demandas burocráticas do exercício docente. Além disso, a condição da mulher docente está carregada de exigências sociais. Ser mulher e professora não é uma tarefa fácil, pois trabalhar fora não "libera" essas trabalhadoras de sua condição social de responsável pela criação dos filhos, organização e higienização da casa. Além das horas gastas na escola, muitas vezes, as mulheres levam trabalho para casa e, fora as atribuições de sua profissão, ainda têm as demandas de sua vida pessoal. Nitidamente, ainda percebemos essas questões nas falas das entrevistadas quando elas se referem à questão da conciliação do trabalho profissional e doméstico, conforme mostra o quadro 5. 
QUADRO 5 - Trabalho profissional e doméstico

\begin{tabular}{|c|l|}
\hline $\begin{array}{c}\text { Como concilia as demandas do trabalho profissional com o trabalho doméstico, a vida } \\
\text { familiar e o trabalho social? (Maridos e filhos auxiliam? Têm empregados/as?). }\end{array}$ \\
\hline \multirow{3}{*}{ Professora M } & $\begin{array}{l}\text { Eu não tenho empregada, minha família me ajuda. } \\
\text { Na verdade, o meu marido me ajuda, porque meu filho é } \\
\text { pequeno. Meu marido colabora bastante, a gente divide bem } \\
\text { as coisas. }\end{array}$ \\
\hline Professora P & $\begin{array}{l}\text { Olha, é tudo bem corrido, tem que organizar bem os horários } \\
\text { pra você dar conta da demanda, porque se a gente não } \\
\text { conciliar, não organizar os seus horários, não consegue fazer. } \\
{[\ldots] \text { Eu tenho que organizar meus horários certinho, senão, }} \\
\text { quando eu saio fora dos meus horários, tudo fica de cabeça } \\
\text { para baixo. }\end{array}$ \\
\hline Professora $\mathrm{K}$ & $\begin{array}{l}\text { Eu faço meu serviço todo sozinha, não tenho nenhuma ajuda. } \\
\text { pra escolia trabalhar. Como eu não tenho ninguém para fazer } \\
\text { meu trabalho e, lógico, como o recurso financeiro não dá, eu } \\
\text { já deixo adiantado o almoço. Aí, quando chego [à] 1h, acabo } \\
\text { de fazer o almoço, dou uma descansada um minuto e já volto } \\
\text { pra cozinha, termino de fazer o serviço e já volto para fazer } \\
\text { minhas atividades, meu planejamento de aula. Meu marido de } \\
\text { vez em quando ajuda. }\end{array}$ \\
\hline Professora $\mathrm{W}$ &
\end{tabular}

FONTE: Entrevistas (2018).

Zibetti e Pereira (2010), em pesquisa que analisou as condições de trabalho da mulher professora, constataram que o tempo que poderia ser reservado a um pequeno descanso é na verdade destinado a fazer planejamento de atividades para a próxima aula e cuidar dos afazeres domésticos. A "ajuda" masculina é apontada como esporádica e assume um caráter de "favor", não sendo propriamente vista como uma divisão igualitária de obrigações.

As professoras da Educação Infantil acabam tendo que se desdobrar para cumprir suas atividades profissionais e pessoais. Isso fica evidente na fala da Professora W, que deve dar conta do planejamento docente, finalizar o almoço e só então descansar. Pinto (2010, p. 73) comenta que "o processo de entrada das mulheres no mercado de trabalho e, especificamente, no caso da profissão do magistério, gerou um acúmulo de papéis sociais 'femininos' ainda hoje reproduzidos”. Esta situação, além de influenciar a qualidade do ensino oferecido às crianças, também é responsável pela deterioração na qualidade de vida das profissionais que, paralelamente às tarefas “domésticas e familiares, ainda precisam dedicar boa parcela do tempo às tarefas escolares" (ZIBETTI; PEREIRA, 2010, p. 268).

Sobre a condição de ser mulher e professora, Costa e Ribeiro (2011) afirmam que o conceito de gênero perpassa as concepções do que é ser professora. As características socialmente atribuídas às mulheres são reproduzidas na atuação 
docente. Para as autoras, o fato de ser mulher anteceder o de ser professora, e isso culmina na definição de estereótipos sobre a prática docente feminina. Esta questão será melhor abordada na seção seguinte.

\section{SER MULHER E PROFESSORA}

Com a Revolução Industrial, apareceram novas oportunidades de empregos. Pinto (2010, p. 54) afirma que "um dos fatores que levaram o magistério primário a se firmar como uma profissão eminentemente feminina foi o fato de a remuneração não ser satisfatória para os homens [...]". A atividade docente feminina não possuía o mesmo prestígio da masculina. Segundo Louro (2006), no final do século XIX e início do XX, é com a feminização do magistério que o ato de educar as crianças na escola vai ser associado à maternidade. Tal associação, para a autora, vai legitimar o abandono da docência pelos homens; eles vão, então, preferir profissões que possibilitem ascensão social e econômica. Esse discurso baseava-se na ideia de que as mulheres, por natureza, teriam uma inclinação natural para o trato com as crianças.

Costa e Ribeiro (2011) analisam as implicações da condição feminina na docência e observam que, nos discursos das mulheres, a admiração por professoras e as influências da família, especificamente das mães, tias e primas, presidem a escolha pela profissão docente. Para as autoras, o entrecruzamento do "ser professora" com o "ser mulher" pode ser notado no sentido de que a profissão docente pode permitir a conciliação entre o espaço público (dar aulas) e o espaço privado (trabalho doméstico). Considerando essa discussão, procuramos saber das entrevistadas como explicavam o processo de feminização da docência na Educação Infantil. As respostas podem ser encontradas no quadro a seguir.

QUADRO 6 - Docência e gênero

\begin{tabular}{|c|l|}
\hline \multicolumn{2}{|c|}{ A maioria dos seus colegas de profissão são homens ou mulheres? } \\
\hline & $\begin{array}{l}\text { São } 100 \% \text { mulher, mas eu já trabalhei em escolas [onde] eu } \\
\text { tive colegas homens. Quando eles começaram a atuar como } \\
\text { pedagogos, sentiram preconceito de alguns pais, mas, no fim } \\
\text { do ano, os pais viram que eles tinham competência. Os dois } \\
\text { que trabalhavam comigo exerceram com competência o } \\
\text { trabalho de pedagogo. Como se fosse uma professora, eles } \\
\text { fizeram o papel direitinho. }\end{array}$ \\
\hline Professora $\mathrm{P}$ & Mulheres. \\
\hline Professora $\mathrm{K}$ & Mulheres. \\
\hline Professora $\mathrm{W}$ & Mulheres. \\
\hline
\end{tabular}

FONTE: Entrevistas (2018). 
Um fator que contribui para que a maioria dos professores da Educação Infantil seja mulher é a questão de gênero que está imbrincada no magistério. A Educação Infantil, que nasce do modelo assistencialista de educação compensatória, sempre esteve associada ao cuidar. A ideia de sacerdócio é invocada como elemento que justifica a docência como eminentemente feminina. Para a sociedade patriarcal, a maternidade é o destino da mulher; assim, nada mais "natural" que o cuidado com as crianças seja a profissão ideal para elas.

Essas concepções se mantêm, quase inalteradas, em muitos discursos e práticas na Educação Infantil. A ideia de dedicação, de sacrifício desinteressado, de missão abnegada está associada à docência nessa etapa de escolarização. Segundo Del Priore (2007), com a entrada das mulheres no magistério, a profissão passa a ser descrita como atividade que requer paciência, minúcia, doação, cuidado. Nota-se que, ao fazer referência à atuação masculina na Educação Infantil, a Professora $\mathbf{M}$ salienta que o trabalho dos colegas foi satisfatório porque eles o realizaram "como se fosse[m] uma professora".

Ainda sobre a questão da feminização do magistério, procuramos saber como as entrevistadas explicavam a predominância de mulheres na educação infantil. Apesar de termos evoluídos em vários setores, as mulheres ainda são vistas como as educadoras naturais das crianças. Reflexo disso é o fato de que os discursos das professoras $\mathrm{Me} \mathrm{W}$ são atravessados por estereótipos de gênero. A ideia da professora como segunda mãe justifica, na opinião delas, a predominância de mulheres no exercício da docência. A Professora $M$ descreve a atividade docente como uma extensão da atividade doméstica; a ideia naturalizada de que toda mulher gosta de crianças também está presente. Essa concepção é bastante reducionista também do ponto de vista do que representa a docência. Acreditar que toda mulher é professora nata e que basta gostar de crianças para ser educadora reflete um posicionamento carregado de valores de classe.

QUADRO 7 - A predominância feminina na educação

\begin{tabular}{|l|l|}
\hline \multicolumn{2}{|c|}{ Por que você acha que há predominância de mulheres na educação? } \\
\hline & $\begin{array}{l}\text { Acho que concilia muito essa coisa de ser mãe, cuidar de } \\
\text { casa. Então, tem mais a ver. É como se fosse uma extensão } \\
\text { daquilo que você tem em casa. Você leva para escola; então, } \\
\text { eu acho que é mais por isso, essa facilidade que as mulheres } \\
\text { têm. É como se fosse uma mãe mesmo, essa facilidade que } \\
\text { nós temos para cuidar de criança. Então, muitas se } \\
\text { identificam com o curso de Pedagogia, porque a maioria das } \\
\text { mulheres gosta de criança, tem apego. }\end{array}$ \\
\hline
\end{tabular}




\begin{tabular}{|c|l|}
\hline & $\begin{array}{l}\text { Em partes, eu acho que ainda há um pouco de preconceito } \\
\text { por parte dos homens. Por outro lado, a maioria dos homens } \\
\text { não tem muito jeito com crianças. Já tive experiência com } \\
\text { isso em um trabalho que tive. Um senhor, quando ele entrou } \\
\text { na Educação Infantil, tinha muita dificuldade, quase perdia } \\
\text { os cabelos. Eu e minhas amigas ficávamos rindo dele, } \\
\text { porque ele não tinha muito jeito e nem tato. É muito difícil } \\
\text { você ver um homem ter jeito e tato para lidar com os } \\
\text { pequenos, principalmente quando tem 30 alunos dentro de } \\
\text { uma sala de aula. }\end{array}$ \\
\hline Professora $\mathrm{K}$ & \begin{tabular}{l} 
Devido ao machismo. \\
\hline Pu acredito que a mulher é muito persistente em tudo. \\
A mulher corre muito mais atrás dos seus objetivos e em \\
ajudar a família. Eu acredito que seja por esse motivo que \\
temos mais mulher nessa profissão, principalmente na área de \\
Pedagogia. E por outro motivo também: é por estar com \\
crianças pequenas. Então, são as mulheres que têm mais \\
habilidade e mais paciência.
\end{tabular} \\
\hline
\end{tabular}

FONTE: Entrevistas (2018).

Nas falas das professoras, pode-se observar que a explicação para a predominância feminina na educação está ligada à suposição de que a profissão exige “características femininas”, que são descritas como inclinação natural das mulheres. Ser mãe, ter mais habilidades e paciência com crianças são atributos apontados como atestados de boa docência. Tais características são negadas aos homens. Aqueles que se aventuram na docência na Educação Infantil sofrem preconceito das próprias colegas mulheres. Costa e Ribeiro (2011) afirmam que essa concepção sobre a docência evidencia que o gênero está centrado em uma matriz heteronormativa quando se refere a atitudes, comportamentos e condutas referentes ao sujeito que se constitui como homem ou mulher. As autoras verificam a rigidez com que o conceito de gênero é percebido.

QUADRO 8 - Predominância feminina na Educação Infantil

Em sua opinião, por que a maioria das professoras da Educação Infantil são mulheres?

\begin{tabular}{|c|l|}
\hline Professora M & $\begin{array}{l}\text { Acho que é porque [...] as mulheres já nascem com o dom de } \\
\text { ser mãe e cuidar das crianças. Por isso, é mais fácil para elas } \\
\text { lidar com crianças. }\end{array}$ \\
\hline \multirow{3}{*}{ Professora P } & $\begin{array}{l}\text { Então, como eu disse, já tive a experiência de ver um homem } \\
\text { trabalhando na Educação Infantil, e ele se via de cabelo em } \\
\text { pé, doidinho dentro da sala de aula. Já a mulher, não. Por } \\
\text { mais que ela ainda não tenha filhos, ela tem mais jeito, mais } \\
\text { carinho, já tem aquele cuidado de mãe. Acho que já vem da } \\
\text { natureza da mulher. Por isso, temos mais mulheres na } \\
\text { Educação Infantil. }\end{array}$ \\
\hline Professora K & É cultural e ideológico. \\
\hline
\end{tabular}




\begin{tabular}{|l|l|}
\hline \multirow{3}{*}{ Professora W } & É exatamente por esse motivo mesmo que eu te disse, por \\
estar trabalhando com criança. Eu acho que as mulheres têm \\
mais paciência com criança. E criança é uma coisa muito \\
preciosa, é uma planta, né?, que nós temos que estar ali \\
zelando a cada momento. É de uma autopsicologia com as \\
crianças, porque ela é um livrinho em branco. Cada dia, ele \\
[faz referência à criança] traz uma novidade pra gente e a \\
gente tem que estar ali pronta pra poder estar escrevendo \\
nesse livrinho em branco, escrevendo coisas boas. Eu acho \\
que esse é o motivo.
\end{tabular}

FONTE: Entrevistas (2018).

Representações sociais são estabelecidas em um dado momento e, posteriormente, desfeitas. Afinal, as representações de professores carregaram, através dos anos, algumas continuidades, mas também se transformaram historicamente (DEL PRIORE, 2007). O quadro 8 explicita que, embora as professoras incorporem em seus discursos o caráter social e ideológico dos papéis atribuídos às mulheres e aos homens na sociedade, ainda se mantêm as mesmas explicações de há séculos sobre os pretensos atributos inatos da mulher. Tais concepções parecem ignorar ou ocultar o caráter ideológico e de gênero da docência. Com a exceção da Professora K, que explica a questão como sendo de ordem "cultural e ideológica", as demais professoras atribuem o predomínio das mulheres na Educação Infantil às consequências das características maternas inerentes à mulher. Essa visão compromete até mesmo os sentidos da atividade docente nesta etapa. A Professora W descreve as crianças e a atividade docente na Educação Infantil do ponto de vista da abordagem inatista. As ideias de tábula rasa, de folha em branco, de plantinhas que precisam de cuidados estão no cerne da concepção assistencialista de educação para a infância.

Del Priore (2007, p. 450) complementa essa nossa análise ao afirmar que "tudo foi muito conveniente para que se constituísse a imagem das professoras como 'trabalhadoras dóceis, dedicadas e pouco reivindicadoras",, o que serviria futuramente para lhes dificultar a discussão de questões de salário, carreira, condições de trabalho etc. Acreditamos que essa concepção da docência feminina influencia os modos de lidar com a educação de meninos e meninas na escola. No quadro 9, apresentamos as concepções das entrevistadas sobre a questão. 
QUADRO 9 - A educação das meninas na escola

\begin{tabular}{|c|l|}
\hline \multicolumn{2}{|c|}{ Como você vê a educação das meninas na escola em que atua? E na sociedade? } \\
\hline Tem umas mães, assim, que preservam a infância da criança, \\
que têm o cuidado de conversar com elas. Mas a gente \\
percebe que muitas famílias que não têm esse cuidado não. \\
Âs vezes, temos que pedir para a orientação chamar alguns \\
pais para conversarmos, para dizer que a educação dessa \\
criança tem que ser mais assistida. E, na escola, não vejo \\
trabalhar a questão de direitos iguais entre mulheres e \\
homens não. Trabalhamos com projetos para orientá-las de \\
forma pedagógica sobre abuso sexual. Só isso mesmo.
\end{tabular}

FONTE: Entrevistas (2018).

A história da busca pela emancipação feminina é marcada por movimentos sociais que permitiram que as mulheres de hoje pudessem votar, ir à escola, trabalhar em qualquer profissão (apesar de sofrerem preconceitos e não receberem os mesmos salários que os homens), mas para a total igualdade de gênero ainda temos um longo caminho a percorrer. Por isso, acreditamos que devemos superar, como disse Bourdieu (2002, sem paginação), "a ordem social [que] funciona como uma imensa maquina simbólica que tende a ratificar a dominação masculina na qual se alicerça: é divisão social do trabalho, divisão bastante estrita das atividades atribuídas a cada um dos dois sexos". 
Conselhos e palavras de ordem interpelam-nos constantemente, ensinam-nos sobre saúde, comportamento, religião, amor, dizem-nos o que preferir e o que recusar, ajudamnos a produzir nossos corpos e estilos, nossos modos de ser e de viver (LOURO, 2006). Nas falas das entrevistadas, fica evidente que a instituição escolar é impermeável a essa questão. Na fala da Professora $\mathrm{M}$, percebemos um sentido moralista sobre as relações de gênero. Instada a falar sobre a questão no âmbito escolar, a entrevistada se reporta à família das crianças.

Nossa escola assume um viés sexista quando estabelece comportamentos esperados para meninas e meninos; quando carrega em seus discursos e em suas práticas as "atividades de meninas e meninos", cores de meninas e meninos. Ajudar a superar essas questões deveria ser também papel da educação formal institucionalizada. Auad (2003, p. 95) afirma que "as professoras e os professores são profissionais muito importantes para criar essa educação e essa sociedade em que mulheres e homens têm os mesmos direitos".

Acreditamos que a escola não pode ficar isolada de um processo amplo de transformação para alcançar a equidade de gênero. O que pode fazer uma professora, de qualquer nível da escala educacional, se ela própria é violentada? O que pode ensinar um professor que é um violador? O que pode fazer a escola se ela estiver desligada de um processo de transformação cultural? Estas questões nos inquietam.

Acreditamos que estudar sobre a trajetória histórica da mulher é indispensável nas universidades. Só assim homens e mulheres terão noção de toda a trajetória feminina, todos desafios enfrentados e as conquistas alcançadas, e as que deverão ainda ser conquistadas. Bourdieu (2002, p. 156) afirma que “[...] a educação fundamental é fundamentalmente política: ela tende a inculcar maneiras de portar o corpo, em seu conjunto ou esta ou aquela de suas partes [...]”. Quando dizemos para as crianças que isso é "de menino" ou aquilo é "de menina", contribuímos para a desigualdade de gênero. É necessário que essas temáticas sejam trabalhadas da Educação Infantil até a universidade. Acreditamos, portanto, que a promoção de uma educação mais igualitária, não sexista e justa passa pela formação das professoras.

\section{CONSIDERAÇÕES FINAIS}

Por meio das análises desenvolvidas neste trabalho, percebemos que as entrevistadas fazem a associação da figura da mulher e da mãe a um ideal de professora. A pesquisa empírica nos levou às seguintes considerações: a questão de gênero 
precisa ser explorada nos currículos dos cursos de formação de professores. Estão presentes nos discursos das entrevistadas as velhas concepções reducionistas sobre o papel da mulher e da docência na Educação Infantil. As falas se sustentam com base no mito da inclinação natural da mulher para o cuidado da infância. A pesquisa mostrou-nos a necessidade de aprofundar a crítica ao processo de naturalização da Educação Infantil. O mito da naturalização da inclinação da mulher para a docência na Educação Infantil descaracteriza o papel da professora e esvazia o sentido da docência.

Ter consciência da nossa condição histórica ajuda-nos a nos percebermos como sujeitos conscientes do nosso papel histórico e social para que possamos deixar de reproduzir essa cultura sexista. Partindo do pressuposto de que é possível mudar a nossa realidade quando temos consciência dela, podemos afirmar que a emancipação só ocorrerá quando compreendermos quem somos e por que somos produzidos dessa forma, por que pensamos de determinado modo e temos certos tipos de comportamentos. Compreender como a nossa história e a nossa cultura interferem nas nossas decisões e ações colabora para que tenhamos comportamentos diferentes e mais conscientes.

Novas pesquisas são necessárias tanto no que se refere à presença desses conteúdos na formação docente, quanto à atuação de professoras que possuem uma compreensão mais ampla dessa temática, com vistas a documentar práticas diferenciadas na educação da infância.

\section{REFERÊNCIAS}

AUAD, D. Feminismo: que história é essa? Rio de Janeiro: DP\&A, 2003.

BOURDIEU, P. A dominação masculina. 2. ed. Rio de Janeiro: Bertrand Brasil, 2002.

BOURDIEU, P. O poder simbólico. 10. ed. Rio de Janeiro: Bertrand Brasil, 2007.

CARVALHO, M. P. de. No coração da sala de aula: Gênero e trabalho docente nas séries iniciais. São Paulo: Xamã, 1999.

COSTA, A. P.; RIBEIRO, P. R. M. Ser professora, ser mulher: um estudo sobre concepções de gênero e sexualidade para um grupo de alunas de Pedagogia. Estudos Feministas, Florianópolis, v. 19, n. 2, p. 467-474, maio/ago. 2011. Disponível em: https://bit.ly/ 2EHxgYj. Acesso em: 23 jan. 2019.

HAHNER, E. J. Escolas mistas, escolas normais: A coeducação e a feminização do magistério no século XIX. Estudos Feministas, Florianópolis, v. 19, n. 2, p. 467-474, maio/ago. 2011. Disponível em: https://bit.ly/2HdwGn6. Acesso em: 08 jun. 2018.

LAJOLO, M.; ZILBERMAN, R. Da chibata ao magistério: a trajetória da educação feminina no Brasil patriarcal. Estudos Feministas, Florianópolis, v. 15, n. 3, p. 823-841, set./dez. 2007. Disponível em: https://bit.ly/2TaF0Ls. Acesso em: 23 jan. 2019.

LOPES, E. M. T.; GALVÃO, A. M. de O. História da Educação: O que você precisa saber sobre. Rio de Janeiro: DP\&A, 2001. 
LOURO, G. L. Gênero, sexualidade e educação: uma perspectiva pós-estruturalista. 6 . ed. Petrópolis, RJ: Vozes, 1997.

LOURO, G. L. Mulheres na sala de aula. In: PRIORE, M. D.; BUSSANEZI, C. (Orgs.). História das mulheres no Brasil. 8 ed. São Paulo: Contexto, 2006.

LOURO, G. L. Educação e docência: diversidade, gênero e sexualidade. Revista Brasileira de Pesquisa sobre Formação Docente, Belo Horizonte, v. 3, n. 4, 2011. Disponível em: https://bit.ly/2BZM9DS. Acesso em: 23. nov. 2017.

PEREIRA, A. C. F; FAVARO, N. A. L. G. A história da mulher na educação e no magistério no Brasil. Paranavaí: Unespar, 2016.

PINTO, C. R. J. Feminismo, História e Poder. Revista Sociologia e Política, Curitiba, v. 18, n. 36, p. 15-23, 2010. Disponível em: https://bit.ly/2h6WaSO. Acesso em: 20 mar. 2018.

PIO, R. M.; FRANÇA, D. L.; DOMINGUES, S. C. A pesquisa na prática pedagógica de professores. Revista Educare, João Pessoa, v.1, n 1, p. 101-115 jun., 2017.

VENTURINI, A. M.; THOMASI, K.; B. A feminização na Educação Infantil: uma questão de gênero. Revista Científica Digital da Faetec, v. 1, n. 1, 2013. Disponível em: https://bit.ly/2C0InK8. Acesso em: 11 jul. 2018.

ZIBETTI, M. L. T.; PEREIRA, S. R. Mulheres e professoras repercussões da dupla jornada nas condições de vida e no trabalho docente. Educar em Revista, Curitiba, n. especial, p. 259-276, 2010. Disponível em: https://bit.ly/2BZK5eY. Acesso em: 10 jun. 2018. 